\title{
Freedom of self-discreditation. On Witkacy's letters to his wife
}

Could Witkacy's letters be entitled, using the words from Edgar Allan Poe's Marginalia, "My Heart Laid Bare"? According to Poe, to write a book which would fulfil the promise in the title was impossible: "Paper would cringe and burn at the very first contact with the heated pen." Baudelaire was the first to decide to fulfil that promise. Did he make a pact with the devil to write a book about himself?"Alas, should it even be published, J.J. Rousseau's The Confessions will seem bland," "thus dreamt Baudelaire, who intended to publish Mon couer mis à $n u$ as his opus magnum. Unfortunately, he only managed to write fragments of it.

Those fragments published under the title Dzienniki poufne included a comparison of literature to the Bull-Leaping Fresco. Michel Lieiris, who over fifty years later than Baudelaire decided to accept the challenge offered by Poe, thus explained the comparison:

To reveal and expose some emotional and sexual obsessions, to confess publicly to one's most shameful flaws, vile tricks, or deficiencies - that is the means used by the author to introduce into a work of literature at least a shadow of the bull's horn. ${ }^{3}$

In Dzienniki poufne, the theme of Bull-Leaping appeared in the ironic comments on the journalist Giradin who said about himself that it was customary for him to "take the bull by the horns." As Baudelaire noted: "Giradin thinks (...) that a bull has its horns on its arse. He mistakes the tail for the horns." In fact,

\footnotetext{
* Mgr, e-mail: sarakurowska@o2.pl, Department of $20^{\text {th }}$ and $21^{\text {st }}$ century Polish Literature, Faculty of Philology, University of Lodz, 91-404 Lodz, 171/173 Pomorska street.

${ }^{1}$ Ch. Baudelaire, Sztuka romantyczna. Dzienniki poufne, trans. A. Kijowski, Spółdzielnia Wydawnicza „Czytelnik”, Warsaw 1971, p. 249. [English version translated from Polish].

${ }^{2}$ Ibid.

${ }^{3}$ M. Leiris, Wiek męski wraz z rozprawka literatura a tauromachia, trans. T., J. Błońscy, Państwowy Instytut Wydawniczy, Warsaw 1972, p. 8. [English version translated from Polish].

${ }^{4}$ Ch. Baudelaire, op. cit., p. 271.
} 
Baudelaire himself took the bull by its horns, as, of course, the bull can be understood as society. On the one hand, Baudelaire tried to adjust to the conditions imposed by society: "he applied to the Academy, and does everything he can to succeed, visiting and writing to renowned figures of the literary world; at the same time, he intends to become the director of the Odéon theatre, and then receive the Legion of Honour."' On the other, he wished to write something, which would prove the impossibility of adjusting. Baudelaire's gesture did not, however, seem dandyish. The artist wished to amaze the urban society, to fence himself from it through exceptionality. "I wish to show my fellow humans the truth of man in the whole truth of his nature; and I shall be that man. I alone," he wrote. That was rather the gesture of the first modern writer, for whom the pressure of social order became unbearable. By uncovering the contradictions in his own mind, he wanted to remind people that man is, in his essence, mad, crazy, and hilarious.

Through the metaphor of a garden, Gombrowicz expressed basically the same thing which Poe described as the "bare heart". The famous sentences of Dziennik read as follows:

My spring spurts in a garden, at the gate of which there is an angel with a fiery sword. I cannot enter. I am never going to get inside. I am doomed to eternally orbiting the place where my truest enchantment glows. I cannot because... those springs spurt shame like a fountain! Yet the internal imperative: come as close as possible to the source of your shame! ${ }^{7}$

And yet Gombrowicz also made a pact with the devil, who showed him a side door to the garden. Yet Dziennik was not it: As Jerzy Jarzębski stated, we are somewhat misled 'by the autobiographic pact', which the author seems to be (...) making by choosing the form of a journal." ${ }^{8}$ Indeed, according to Lejeune's idea, "the fact of the inclusion of the same name on the cover and in the text, and the first person form of expression" indicates the conclusion of an autobiographic pact, which in turn entails a referential pact, which "can be summed up in the formula 'I promise to say the whole truth and nothing but the truth."'10 Gombrowicz did state in Dziennik: "this Satan of mine, here, is a creature made of accidents

${ }^{5}$ Ibid., p. 250.

${ }^{6}$ Ibid., p. 249.

${ }^{7}$ W. Gombrowicz, Dzienniki 1957-1961, Wydawnictwo Literackie, Krakow-Wroclaw, p. 110. [English version translated from Polish].

${ }^{8}$ J. Jarzębski, Podglądanie Gombrowicza, Wydawnictwo Literackie, Krakow 2000, p. 182. [English version translated from Polish].

${ }_{9}^{9}$ M. Czermińska, Autobiografia i powieść czyli pisarz i jego postacie, Wydawnictwo Morskie, Gdansk 1987, p. 11.

${ }^{10}$ Ibid. 
and waste (...), like the barking of a dog, a parrot, no answer, paper, Tigre... (...)"11 so one could assume that he presented himself through various authentic random waste from his life. However, as Jerzy Jarzębski argued:

Gombrowicz's Dziennik serves more a creative than a reporting function (...) [The author] basically creates himself the protagonist. That is why the narration of Dziennik also aims at the future, i.e. towards that future moment when there will form a finished reasonable structure, which the author tries to create. ${ }^{12}$

Therefore, Gombrowicz, similarly to Witkacy, wished to control random events, and instead of himself, he offered only some fabricated construct. "A writer (...) who overtly confessed that he wanted to be liked, had no place in the brutal striptease,"13 concluded Jan Błoński. The most brutal of all stripteases was, of course, Gombrowicz's unfabricated secret journal, i.e. Kronos.

In Polish literature, even after 1945, regardless of the popularity of publishing journals, writers were rarely willing to perform such a feat as Baudelaire's. It comes as no surprise that an interwar artist, who wrote his most important journal in letters, did not want to turn his life into Mon couer mis à $n u$ - another novel in instalments, and warned his wife: "(...) I cannot write about this because I do not wish to burn my letters. And if they fall into anyone's hands after I die, I shall be discredited (and you as well) (...)"14 Jadwiga, of course, complied with the request to burn the letters, and thus the paper couple, so to speak since they communicated mainly via post, established a special kind of a correspondence pact.

Warily, Witkacy reminded his wife every now and again about the agreement: "just remember, that my matters are only and exclusively for you to know." 15 Some postcards were brandished with an amusing stamp: "do not read. For my wife on $1 \mathrm{y}$," s o m e o ne e $1 \mathrm{~s}$ e's." ${ }^{\prime 17}$ Let me add that the stamp could only be considered as amusing as it would be doubtful that Witkacy was warning some "other wife"

${ }^{11}$ W. Gombrowicz, op. cit., p. 305.

12 J. Jarzębski, op. cit., p. 182.

${ }^{13}$ J. Błoński, Forma, śmiech i rzeczy ostateczne. Studia o Gombrowiczu, Towarzystwo Autorów i Wydawców Prac Naukowych Universitas, Krakow 2003, p. 120. [English version translated from Polish].

${ }^{14}$ S.I. Witkiewicz, Ldż (1923-1927), Państwowy Instytut Wydawniczy, Warsaw 2005, p. 58. [English version translated from Polish].

${ }^{15}$ Idem, Ldż (1928-1931), Państwowy Instytut Wydawniczy, Warsaw 2007, p. 257. [English version translated from Polish].

${ }^{16}$ Idem, Ldż (1932-1935), Państwowy Instytut Wydawniczy, Warsaw 2010, p. 278. [English version translated from Polish].

${ }^{17}$ Ibid., p. 274. 
against reading his letter. He did, in fact, state that "he is even less surprised by gossiping women since he himself displayed huge interest in gossip (...)"18 Just in case, though, none of the stamped postcards included any intimate details.

In a letter to his wife dated 1 October 1928, Witkacy wrote:

I am terrified that you burn all (!!) attachments. I included in them all class 1 specimens!! Asz's letter, the Strążyski card, and Reynel's envelopes (and cards). That was a terrible and unexpected blow. Who could have anticipated that and stipulated against it? Awful. ${ }^{19}$

Jadwiga evidently did not react, as in the following letter Witkacy inquired impatiently: "tell me if you have already burnt the priceless museum pieces." 20 How is it possible that Witkacy, director of a superb theatre of life, could had expected that his wife, who by no means was a demonic woman, rather "a good reliable person from a proper family, and very well brought up" ${ }^{21}$ would perform before him a theatre of letter burning?

The title My Heart Laid Bare could also be assigned to the diary which Witkacy wrote during his visit to Russia. In Wojna Witkacego..., Krzysztof Dubiński exposed Witkacy's not exactly Romantic-heroic but rather cowardly heart. In his letters, Witkacy ordered his wife to keep his diary locked in a cabinet. ${ }^{22} \mathrm{He}$ had more luck with his diary, which burnt during the Warsaw Uprising, than with his letters.

Why was the artist so afraid or even terrified of his letters being read by someone other than Jadwiga? Micińska and Degler stopped at Witkacy's own explanation: "to poke around in an author à propos his work is indiscreet, inappropriate, and dishonourable." ${ }^{23}$ At the same time, they did not consider their interest in the author's private life as "poking around." Rather as "brushing" 24 his person of a layer of dirty legend and gossip. While, in fact, such arguments as indiscreetness, inappropriateness, or dishonourable conduct do not justify anything, one should rather make them the starting point and inquire: why was Witkacy such a fierce opponent of biographism?

${ }^{18}$ S. Okołowicz, "Nieznana kobieta w życiu Witkacego. Listy Stanisława Ignacego Witkiewicza do Marii Zarotyńskiej” in: A. Żakiewicz (ed.), Materiały sesji poświęconej Stanisławowi Ignacemu Witkiewiczowi w 60. rocznice śmierci, Słupsk 1999, p. 249.

${ }^{19}$ S.I. Witkiewicz, $L d \dot{z}(1928-1931)$, p. 35.

${ }^{20}$ Ibid., p. 36.

${ }^{21}$ Idem, Ldż (1936-1939), Państwowy Instytut Wydawniczy, Warsaw 2012, p. 287. [English version translated from Polish].

22 Idem, Ldz (1932-1935), p. 278. [English version translated from Polish].

${ }^{23}$ Idem, Pożegnanie jesieni, Wydawnictwo Zielona Sowa, Krakow 2010, p. 9.

24 A. Micińska, Istnienie poszczególne: Stanisław Ignacy Witkiewicz, Wydawnictwo Dolnośląskie, Wroclaw 2003, p. 269. [English version translated from Polish]. 
In an article "Dalszy ciąg o wstrętnym pojęciu niezrozumialstwa", instead of "master critics" Witkacy wrote "bastard critics", and raved in a letter to his wife: "terrible verification - whether Zofia is not careful, or whether she is not doing it" ${ }^{25}$, and on top of that he cannot exact from Przeglad Wieczorny a correction, so he complained to his wife again: "for 2 weeks 4 people in Poland can remember that I called them bastards." 26 One could joke that like as in the Freudian slip, Witkacy expressed that which was hidden. Just like the fierce struggle with Dada and futurism, the struggle with biographism also derives from a fear, in that respect a fear of a contemporary critic who crawls into a work of art, and performs increasingly more extensive analyses. The background for Witkacy's anti-biographic attitude was modernism's multiplying instances of obscuring a work of art with its creator, a legend, or a bromide. Witkacy tried at all costs to defend the concept of an immanent work, enclosed in its formal structure.

The conflict between a biography and a work of art is part of something much more serious, something which Witkacy understood as a tension between metaphysics and contemporary culture with all its prosaic and common character. Art, he argued, is supposed to resemble savouring the refined formal taste, not just a brutal cramming with life's matter.

Within the Pure Form (Czysta Forma) concept, Witkacy tried to suppress life's matter. He passed it over in silence as being unimportant, yet necessary; necessary because man is not a deus artifex, the perfect constructor capable of creating solely with his logos. He also included as works of art thoughts, feelings, and visions, everything to which Witkacy referred concisely and contemptuously as "guts". Why guts? One could venture an analogy. Man shall not achieve intoxicating spiritual heights without previously delivering their gut nutrients. As Márai concluded: man is man, a spiritual being, "not only through the heart and mind, but also through the stomach and intestines." ${ }^{27}$ Pure Form art also seemed not free from ingestive issues. The mystery of Existence must, unfortunately, pass through the gut filled with low, filthy life's content, only to emerge in a Pure Form work of art upon intellectual operations which reduce that which is redundant. Thus content undergoes "angelisation" into a Pure Form work.

Pure art is created by spiritual aristocracy, schizoids as Witkacy used to call them using Ernst Kretschmer's terminology. They possess an innate aversion to guts, "always cocooned in some spiritual wadding." 28 That is why they avoid

${ }^{25}$ S.I. Witkiewicz, $L d \dot{z}$ (1923-1927), p. 154.

${ }^{26}$ Idem, Ldż (1923-1927), p. 162.

${ }^{27}$ S. Márai, Księga ziól, trans. F. Netz, Spółdzielnia Wydawnicza „Czytelnik”, Warsaw 2011, p. 68. [English version translated from Polish].

${ }^{28}$ S.I. Witkiewicz, Narkotyki. Niemyte dusze, Państwowy Instytut Wydawniczy, Warsaw 1993, p. 163. 
"rancorous geniality and exuberance of pyknics"29, i.e. those who are their opposites. Witkacy summarised Kretschmer's work in Niemyte dusze to prove that it is worth using. What was the most interesting, though, was the autobiographic remark placed on the side:

The book [Körperbauund Charakter] (...) has made a formal revolution inside me (...) opening before me (being a leptosom-schizotymic, I can almost say: "a former" - as I have pykniced since them) unforeboded horizons. ${ }^{30}$

Witkacy included the short comment in brackets as being marginal, while, in fact, it seems more important than the summary of the work, which even then was considered as a non-academic simplification, as he openly mentioned his fundamental spiritual transformation. That public confession could be supplemented with the words from the Foreword to Narkotyki:

Currently, I am a relatively cheerful individual of medium age, who in none of his grand exploits can dream, and only wishes to, for better or for worse, end this life, in which despite his failures and mishaps he regrets nothing. We'll see what life brings next. I must only note that this little work shall possess a highly personal, i.e. somewhat posthumous nature. ${ }^{31}$

Witkacy, of course, was ironic about his "tragic situation." When stating that Marceli, Izydor, and Rustalka washed everyday using Brother Sennewaldt's brushes, he added:

there were more and more of those then. That was spurred by a book on drugs by S.I. Witkiewicz, the only work by the author which he deigned to advertise for the benefit of all. ${ }^{32}$

When Witkacy, the creator of Pure Form, wrote about himself that his "little work" is a "highly personal" volume, i.e. gutless, he expressed the highest possible irony. One could say that Witkacy became the embodiment of Baudelaire's vision:

One evening, a man, who stole from fate a few hours of delight, engrossed in the pleasure of digesting, having forgotten, as much as it is possible, about the past, sat-

${ }^{29}$ Ibid., p. 163.

${ }^{30}$ Ibid., p. 154.

${ }^{31}$ Ibid., p. 8.

32 Idem, Jedyne wyjście, Państwowy Instytut Wydawniczy, Warsaw 1993, p. 110. [English version translated from Polish]. 
isfied with the present, and indifferent to the future, intoxicated with his peace and dandyism, proud that he has not stooped so low as those which he sees as he passes them, with his sight fixed on the smoke from his cigar, says to himself: "What do I care what those creatures burdened with conscience strive for?" 33

Was it really the case, as suggested by Micińska, that Narkotyki and Niemyte dusze were written by an artist who "understood himself in relation to society" 34 ? I believe that rather by a catastrophist who became indifferent to the catastrophe, who still hoped that he was capable of a more noble mode of digesting life's content.

Can one specify the time of Witkacy's transformation into a pyknic? Kretschmer's theory was presented in 1936 by a pykniced artist but he came into contact with it as a schizoid artist. The book could had made its way to Witkacy's hands in 1921 at the earliest, straight from the Berlin printers. In any way, he probably read it before 1925 as it was in the mid-1920s that the spiritual aristocrat began to pyknic. He "betrayed", as noted by Micińska ${ }^{35}$, high art, and hiding under the cloak of a short affair with the novel, which in his view was a low form of art, he immersed in life's content. His clear aversion to the guts in the early theoretical papers turned into ambivalence in his novels.

In the foreword to Pożegnanie jesieni, Witkacy established a novel pact with the readers without any, it would seem, analogy in literature. Let us record that pact as yet another example of Witkacy's rules and regulations:

"Rules and Regulations of the Novel Company" 'S.I. Witkiewicz'36

1. The company made a reservation stating that it did not consider the novels it produced as works of art as a novel as such did not meet the principles of Pure Form, i.e. the dominance of formal elements over life's content.

2.Therefore, what has already been stated herein, the company reserves the right to include in a novel any and all elements regardless of the laws of composition, from an unpsychological row to something which could verge on a philosophical or social treatise. ${ }^{37}$

3. Any association of life's content with autobiographical elements is $a b$ solutely prohibited. We emphasise this section the most as

\footnotetext{
${ }^{33}$ Ch. Baudelaire, op. cit., p. 268.

${ }^{34}$ A. Micińska, Istnienie poszczególne..., p. 206. [English version translated from Polish].

${ }^{35}$ Cf. Ibid., p. 172.

${ }^{36}$ The analogy seems even more justified as Witkacy did not consider novels, just like portraits, as works of art.

${ }^{37}$ S.I. Witkiewicz, Nienasycenie, Wydawnictwo Marek Derewiecki, Kęty 2013, p. 7. [English version translated from Polish].
} 
it is most difficult to prevent ${ }^{38}$ a reader from poking around an author à $p$ r o $p$ o s his work $k^{39}$.

4. Any divergence from the provisions of the above section is allowed only in situations when the company shall brand a given remark in a novel with a stamp with their surname.

5. Please read the rules and regulations carefully. Without any executive powers, it counts on the sensitivity and good will of the readers regarding the adherence to the provisions. The fact of reading and agreeing with the rules and regulations shall be deemed equivalent to concluding an agreement. Any and all discussions regarding the rules and regulations are inadmissible. ${ }^{40}$

Let us consider what Witkacy actually said when concluding such a pact. Also note how he fulfilled it in practice.

Since novels are not Pure Form, that means that they are filthy and gutty. Furthermore, that they consist of the uncleaned necessary life content marginalised by Witkacy, or, if one was to expand that analogy even further, autobiographic content. Witkacy was well aware of the dangers resulting from a prying reader, who cannot notice the difference between life's content and autobiographic elements. That was why he hastily constructed consecutive subsections of the pact warning the readers against trying to find an autobiography in his novel. In the foreword to Nienasycenie, he engaged in polemics with critics, e.g. Karol Irzykowski, who reproached Witkacy for establishing his previous novel too much on personal experience. Witkacy was outraged: "how dare those gentlemen presume such things" "'? He even concluded: "it is even more peculiar that not even one fact in Pożegnanie jesieni corresponds to reality." ${ }^{\prime 2}$ And yet Pożegnanie jesieni, though having various distortions, possessed a strong presence of the element of similarity, i.e. that which Lejeune referred to as "the extra-textual point of reference, which is the prototype, or even better, a model for the subject of an expression." ${ }^{43}$ In Powieści Witkacego. Sztuka i mistyfikacja, Bocheński wrote about the analogy between the suicides of Zosia Osłabędzka and Jadwiga Janczewska. Both "occurred in the 'sublime' scenery of a mountain valley, both women killed themselves with shots from their partners' revolvers" "4, while the suicides of the women evoked "suicidal attacks" in their partners:

\footnotetext{
${ }^{38}$ Cf. Idem, O czystej formie i inne pisma o sztuce, Państwowy Instytut Wydawniczy, Warsaw 2003, p. 29.

${ }^{39}$ Cf. Idem, Pożegnanie jesieni, p. 9.

${ }^{40} \mathrm{Cf}$. Idem, O czystej formie..., p. 30.

${ }^{41}$ Idem, Nienasycenie, p. 9.

42 Ibid., p. 10.

${ }^{43}$ M. Czermińska, op. cit., p. 12.

${ }^{44}$ T. Bocheński, Powieści Witkacego. Sztuka i mistyfikacja, Wydawnictwo Uniwersytetu Łódzkiego, Lodz 1995, p. 89. [English version translated from Polish].
} 
Atanazy's visit to the tropics, and Witkiewicz's participation in Malinowski's ethnological journey to Australia, regardless of all the differences, were a kind of a remedy for aching souls. One should also note the baffling similarity between the visit to the country in the midst of the novelistic revolution, and Witkiewicz's return from Australia to Russia upon learning about the outbreak of WWI. ${ }^{45}$

One could say that Witkacy's play in revealing and concealing had a fundamental significance. Bocheński argued that Witkacy simultaneously played out "two theatres, which cannot be separated - the theatre of the peculiarity of existence, and the theatre of banal reality." ${ }^{46}$ Using various side doors, "the actor can easily transit from one scene to another." ${ }^{\text {"47 }}$ Without going into detail about Witkacy's tactics of public self-creation, I only wish to indicate some similarities it shared with the previously mentioned tactics of finding "side doors to the garden" posited by Gombrowicz. Witkacy even used the similar metaphor of a garden. In a letter to Jadwiga, he defined writing Pożegnanie jesieni as "making my way through a thicket of my own psychophysiology." only the "status of his physiology" that he meant when on 3 June 1925 he wrote to his wife: "(...) you cannot imagine what awful ghastliness I need to remove. I let the garden overgrow, and now I've been weeding it for hours. ${ }^{349}$

In the case of Witkacy, similarly to Gombrowicz, that which is hidden is actually an act of revealing oneself. Witkacy relentlessly, mainly in novels, revealed himself indirectly in order not to reveal he was a gutter. He concluded with his readers a novel pact, which was to protect him from the readers searching for him there where he was actually hiding. And yet the pact had the opposite result to the intended one. "I have the impression that I am an exception in this instance - I have never read anything like this about anyone else," ${ }^{50}$ complained Witkacy when "caught" by the critics in Pożegnanie jesieni for his privacy, and attempting to conclude a more efficient pact in the foreword to Nienasycenie. He began with digressions regarding the novel only to blare involuntarily a moment later his chant on the demise of art, which everyone knows so well, and which he interrupted himself because, alas, his intention was to prevent the artist from declining into biography: "I shall not fight for general principles with individual critics (...) - I wish to limit myself to only one problem: the relationship between an author's

\footnotetext{
${ }^{45}$ Ibid.

${ }^{46}$ Idem, "Dwa teatry Witkacego", Napis. Pismo poświęcone literaturze okolicznościowej 2012, Seria XVIII, p. 209.

${ }^{47}$ Ibid.

${ }^{48}$ S.I. Witkiewicz, $L d \dot{z}$ (1923-1927), p. 85.

${ }^{49}$ Ibid., p. 55.

${ }^{50}$ Idem, Nienasycenie, p. 9.
} 
private life and his work." ${ }^{51}$ And yet the following pact also proved unsuccessful, and Witkacy continued to "hear in the judgements of the critics one single evaluation, divided into specific roles, an opinion expressed by the father regarding 622 upadków Bunga, that the novel is terribly personal. To desire art, but to write a biography - that seemed for Witkacy a "hellish surprise" ${ }^{52}$.

The situation was different in non-literary material. There Witkacy would very often make himself the protagonist, thus concluding an autobiographic or referential pact. Bocheński argued that by talking about himself directly, the artist revealed from his intimacy that which fitted his image of an artist - "he changed, censored, deformed" 53 , making himself a type of deceptive figure in a public theatre. He offered the audience which tried to crawl into his works and his private life not himself, but some invented construct. Yet he acts not only in front of them: "in his deformation of the world, his own deformation to such an extent to conceal the knowledge of himself was of great importance." 54

That is why one cannot agree with Micińska, who argued about Witkacy's correspondence with his wife that: "“tis the only (...) 'novel behind a novel' of its kind, one more still of Witkacy's 'sack novels' - in that instance an autobiographic psychological novel." ${ }^{55}$ It rather seems that the letters revealed the autobiographic nature of Witkacy's novels, and as a result: he undermined all pacts which he had concluded with his readers.

Witkacy had been developing matrimonial plans ever since his youth. Why would he want to marry since being an anti-traditionalist he hated "sentimental kitsch" "56? In a letter of 20 January 1923, he inquired of Bronisław Malinowski which of the two candidates he should choose: the pretty blond or the intelligent Jewish girl. In the following letter of 10 March, his boyhood friend found out that Witkacy had already chosen, but neither of the previously presented candidates. He thus wrote of his fiancée, Jadwiga nee Unrug:

(...) she is not v. pretty, yet v. nice. She doesn't love me one bit, and she's not even attracted to me. But that's beside the point. She doesn't possess any material goods, but she understands what fantasy in life and outside of it means. ${ }^{57}$

\footnotetext{
${ }^{51}$ Ibid., p. 8.

${ }^{52}$ T. Bocheński, O pożądaniu u Witkacego, an article made available to me by its author, will be included in a volume being prepared for printing after a conference in Słupsk Witkacy 2014. Co jeszcze jest do odkrycia?

${ }^{53}$ Ibid.

${ }^{54}$ Ibid.

${ }^{55}$ A. Micińska, Istnienie poszczególne..., p. 271.

${ }^{56}$ T. Bocheński, Dwa teatry Witkacego, p. 212.

${ }^{57}$ S.I. Witkiewicz, Listy I, Państwowy Instytut Wydawniczy, Warsaw 2013, p. 672-673. [English version translated from Polish].
} 
It is difficult to agree with Degler's opinion that "for both it was simply a marriage of convenience." ${ }^{58}$ On the contrary, it was rather supposed to be part of Witkacy's fantastic theatre of existence. At the very moment of contracting it, the artist was performing as if in a theatre of Pure Form. He neglected the conditions which determine the actions of individuals contracting marriage: emotional, material, and, finally, for him the most trivial, procreational conditions. It is worth remembering Witkacy's comedy of engagement told by the fiancée herself:

The first words that Staś uttered were: "Would you like to become my wife," and upon receiving my consent, he was extremely thankful, and immediately asked me how important was it for me to have children, because he would prefer not to have them for fear that they would not be satisfactory since both of us are, to some extent, degenerates. I consented to that proposal as well. ${ }^{59}$

That reason was also included in Pożegnanie jesieni. In the "farewell" letter to her husband, Zosia wrote: "you will not have a degenerate son, because I'm taking him with me" 60 , while the husband, despite his overwhelming remorse caused by the death of his wife, felt a relief for the might-have-been fatherhood.

The theory to which Witkacy referred was, of course, one of determinism. When explaining Witkacy's aversion to fatherhood, Degler made it the starting point, but he also expanded it considerably. He referenced the artist's childhood experiences associated with the affair between his father and Dembowska, and stated: "who knows whether the fear of a similar story repeated in his marriage, which influenced the mind of a child, did not become the reason for his abandonment of fatherhood." ${ }^{61}$ The phrase "a similar story could have repeated itself" subtly expressed the supposition that since Witkiewicz the father betrayed his wife, then Witkiewicz the son and Witkiewicz the grandson would be similar monsters. However, the researcher treated the deterministic theory more seriously than Witkacy, who obviously knew about Mendelian inheritance, which undermined it. Yet it was not the Mendelian inheritance that seemed the most important, rather the fact that Witkacy drew egotistic pleasure from being a decadent. Moreover, it was rather others, not him, who were degenerated. Even when he noticed his progressing demise from schizoid to a pyknic, he retained the awareness of an artist who can talk about the end of art, i.e. the end of individuals, the end of the world, endlessly.

${ }^{58}$ J. Degler, Witkacego portret wielokrotny. Szkice i materiaty do biografii (1918-1939), Państwowy Instytut Wydawniczy, Warsaw 2014, p. 164.

${ }^{59}$ S.I. Witkiewicz, Ldż (1936-1939), p. 560.

${ }^{60}$ Idem, Pożegnanie jesieni, p. 309.

${ }^{61}$ J. Degler, Witkacego portret wielokrotny..., p. 222. 
Therefore, if it was the "matter" of fatherhood, a different justification seems more believable. In Jedyne wyjście, he expressed it as follows:

He completely forgot who he was, that he can have a child - while, in fact, that terrified him the most, the sense of extreme responsibility for the fate of an unknown creature in such dangerous times ${ }^{62}$.

He wrote the same in a letter to his wife: "I am actually glad that we do not have children. In today's world, to bring up a son is a hellish task." ${ }^{63}$

Though Witkacy distanced himself from the deterministic theory, he treated his catastrophic theory quite seriously. He believed that through mind-based order he could construct historical order. The result is, obviously, extremely negative: the further he was from the Renaissance, the more terrible each epoch seemed to him.

When Jadwiga became pregnant, she had to, pursuant to the agreement concluded during the engagement, as noted by Degler, "undergo the procedure." ${ }^{4}$ Such a pristine expression did not reflect the truth about abortion in the interwar period, on which Boy-Żeleński wrote in Piekło kobiet as procuring abortion using a crochet hook. Witkacy himself didn't use a euphemism. On the day of the operation, he wrote to his wife:

For the success of your operation, it has already been 4 days since I last smoked, and I feel much better for it. I'm awaiting news from you impatiently. I am curious about your experience of the anaesthesia. Apparently, there are no great pains, and that comforts me. (...) No news from the front as I have left my case for witnesses à discrétion to solve it for good (...). Maybe they are carving you open, and scraping at the moment. Good Lord, what I would give to see it!!!65

Did the artist express in those words concern for his wife's situation, as was suggested by Degler? Rather the opposite. Witkacy, who himself sent Jadwiga to the operating table, was not concerned but excited. One could say that he was vicariously, through the midwife's hooks, torturing Jadwiga. But the torture should probably be expressed through metonymy: it was not Witkacy that tortured Jadwiga, it was his powerful theoretical mind that was doing it. A mind which through his wife's carnality fulfilled its theory regarding giving birth to children, i.e. de facto according to his artificial theory he shaped the grey matter of reality. And he also tried to manage art. The remark about not smoking was, in

\footnotetext{
${ }^{62}$ S.I. Witkiewicz, Jedyne wyjście, p. 35.

${ }^{63}$ Idem, Ldż (1932-1935), p. 226.

${ }^{64} \mathrm{~J}$. Degler, Witkacego portret wielokrotny..., p. 222.

${ }^{65}$ S.I. Witkiewicz, Ldż (1923-1927), pp. 77-78.
} 
fact, a gesture of theatricalisation of the creative process known from Witkacy's paintings: toying with various psychoactive substances, and half-seriously observing their influence on his art. Therefore, the artist's not smoking was just like trying to find the appropriate artistic form of expression. He regretted that he could not apply his clear mind devoid of nicotine to see how on the operating table they were carving his wife open. Therefore, it seems justified to compare abortion to a work of art. And if so, then to a female act in particular. What I mean, though, is not the conventionalised genre, but L'Origine $d u$ monde by Gustave Courbet.

Courbet's painting evoked such extreme emotions that for the major part of the $20^{\text {th }} \mathrm{c}$. it was not displayed publicly. Why if such acts have been made since antiquity? Thierry Savatier argued that in the case of Courbet's painting, one does not actually view an act in the sense as it has been defined by culture. The breaking of the convention was emphasised by the painter by reducing a woman to a certain fragment - he omitted her head. According to Savatier, Courbet's intention was:

the presentation of that which has previously been missing from the female act, to present a full-blooded woman, meaning... nothing more or less than her vitals! ${ }^{66}(\ldots)$ through the topic and the framing, the painting immediately seems a symbol of creative freedom, released from all moral limitations or, more precisely, all limitations of "moralising morality". (...) According to all sorts of censors, L'Origine du monde has no right to be considered a work of art. It remains that thing, in other words: a work, in any case, surely "pornographic". ${ }^{67}$

When Witkacy was creating his act in his imagination, it was as if his wife stopped existing for him, she lost her face. Similarly to Courbet, he only saw the very frame of the female procreative organs. Contrary to Courbet's painting, Witkacy's act could bear the name The End of the World, as the artist, due to his catastrophic vision, did not want to give the world the creative element of himself. The act of annihilation of a being became for him a private act of creation, a theatre of cruelty, and a transgression into the artistic zone. The peculiar combination of eroticism and death seemed to be extremely attractive for Witkacy. It was further amplified by the news of an honorary matter with Karol Stryjeński. He expressed the apparent shift from a matter of honour to the fact that at the very moment they might be cutting his wife open through deep synchronicity. Consider that Witkacy thought he himself was one step away from dying, that he was going to

\footnotetext{
${ }^{66}$ T. Savatier, Poczatek świata. Historia obrazu Gustave'a Courbeta, trans. K. Belaid, słowo/ obraz terytoria, Gdansk 2015, p. 13. [English version translated from Polish].

${ }^{67}$ Ibid., pp. 11-12.
} 
duel Stryjeński "till first blood" ${ }^{8}$, and at the same time, in his imagination, he saw an act, which actually consisted of spilling blood, and killing his offspring.

Witkacy left a trace of enthralment in the peculiar synchronicity between eroticism and death in Nienasycenie. When Genezyp finds out that his father died at six in the morning, he tried to recall what he was doing at that time:

What was I doing at six! Oh, oh - it was her who showed me that combination with the legs then! How obscene! And he at the same time. "At the same time" - falling, he could not satiate with that word. Now the "found out" death of father amplified retrospectively the already deadly pleasure of touching those legs, so badly, inexorably beautiful and indecent, four hours prior - and at the background of simultaneity, and not even current, but recollective, rather notional and abstract. ${ }^{69}$

That synchronicity could be further amplified. The night when the old Kapen died, was the first night Zypcio spent with the duchess, with whom his father had had an affair.

Witkacy, similarly to Genezyp, was amazed at the exceptional nature of the moment. That feeling was born out of the framing of various random elements, thus an incarnation of Pure Form in life. Incarnation seems the right word in the context as it indicates the source of Pure Form. Something that Witkacy wanted to see as a pure intellectual experience, in reality comes from the depths of the gut. A somewhat similar ironic turn of events applied to Duchamp. As everyone knows, he wanted to remit painting to be governed by intellect, and it was actually Courbet whom he blamed for "giving the art of the $19^{\text {th }} \mathrm{c}$. a solely 'retinal' trend" 70 . Paradoxically, L'Origine du monde became a direct inspiration for Étant donnés, a work on which Duchamp worked secretly during the final twenty years of his life.

When in the letter to his wife, Witkacy used the term "rżnąć" (carve open), he, of course, did not only mean the fact of cutting her with a scalpel. [The word "rżnaćc" has two meanings in Polish: (i) informal to cut, and (ii) to fuck someone] Already Baudelaire in his Dzienniki poufne wrote that:

the act of making love bears similarity to torture or a surgical operation. ${ }^{71}$ That thought, though, could be expanded rather bitterly. Even if both lovers desire each other, one of them will always be calmer, and less wild than the other. Either he or she will be the operator, i.e. the butcher; the other being the object; the victim. ${ }^{72}$

${ }^{68}$ The term used in the title of a book by J. Rawicz: Do pierwszej krwi, Warsaw 1974.

${ }^{69}$ S.I. Witkiewicz, Nienasycenie, pp. 155-156.

${ }^{70}$ C. Tomkins, Duchamp. Biografia, trans. I. Chlewińska, Zysk i S-ka Wydawnictwo, Poznan 1996, p. 421. [English version translated from Polish].

${ }^{71}$ Ibid., p. 261.

${ }^{72}$ Ibid., p. 254. 
As it is commonly known, in his youth, Witkacy was tortured sexually by Irena Solska who often betrayed him. From a combination of personal experiences, and a fascination with Mirbeau's novel, he created on canvas his own Torture Garden. It would be difficult not to have the impression that in his marriage with Jadwiga, it was Witkacy that was the butcher. "You seem to think that if you give me freedom, I will screw whores in your bed," 73 he wrote to her in one of his letters. As we know, Jadwiga did not share her husband's amazement in the fullness of the moment during the abortion. In time, though, the ambivalent language of sex became an element of a correspondence pact which bound them.

In the foreword to Pożegnanie jesieni, the artist also included low language in the novel pact:

Ever since Berent printed the word "son of a bitch" (...), and Boy a sentence which included the phrase "screw like wild asses" (...), I believe that you can sometimes stop feeling embarrassed, as long as it is worth it on another level. ${ }^{74}$

Of course we all know on what level that was. If Witkacy used the phrase "be worth it", that in no way applied to the economic register. He wrote directly about that which was supposed to be worth it in one of his polemical articles:

Here I absolutely demand the writer to tear me par force using his particular means, those which he uses for himself, from this reality in which I live, and show me the world anew within the levels of its metaphysical mystery and beauty. The author can, by the way, abuse me in all terrible ways provided he pays me on a different level: (...) he can even toss me into the sump of life provided that he will bathe me afterwards using some metaphysical fluid, and pull me up onto some unknown peak, the view from which shall make up for the horrors of the lows, amplifying the beauty of the dread of peak phenomena $(\ldots)^{75}$

From Witkacy's letters to his wife we know that when he was writing Pożegnanie jesieni, he was testing the peculiar recipe of Stroniewicz. The physician ordered him sexual abstinence explaining that "everything resides in the balls." ${ }^{176}$ Witkacy, who had already expressed his rebellion against spawning children, began to understand the creative process through a literal analogy to procreating. In that sense one could include him in the previously-mentioned group of the "metaphorical". In an interview with Damaso Alonso, Rita Malú supposedly

${ }^{73}$ S.I. Witkiewicz, Ldż (1928-1931), p. 188.

74 Idem, Pożegnanie jesieni, p. 7.

${ }^{75}$ Idem, Pisma krytyczne i publicystyczne, Państwowy Instytut Wydawniczy, Warsaw 2015, p. 388. [English version translated from Polish]

${ }^{76}$ Idem, Ldż (1923-1927), p. 101. 
stated: "you, men, have your balls filled with angels." ${ }^{77}$ According to Vila-Matasy, the author of Literatura przenośna, "that sentence leads us to the precise semenal trend of that potential energy, which was the core of shandism." ${ }^{\prime 78}$

In Witkacy's reports on the work on Pożegnanie jesieni he offered his wife, there appeared another word which emitted an ambivalent sexual tone. On 26 July 1926 he wrote:

(...) I've gone on a craze, and I'm striking terrible things: homococo of Atanazy with Lohoyski. (...) I think (though slightly) that when I botch this novel, there will open a new horizon of stage arts of a new type in front of me, one which I sense in my metaphysical sleeve $(\ldots)^{79}$

Less than a month later, he reported to his wife:

(...) I'm so tired I'm almost unconscious, yet I must strike on. I'm nearing the end, and maybe tomorrow I will complete the notepad. Since my arrival from Lviv, I have written over 80 pages of the wildest things. I'm sending all my sexual energy into that manuscript. But I'm afraid of overdoing it. What will Steinberg say! $!^{80}$

Apparently Witkacy, who in the 1920s began pyknicing, was deluding himself that he could pay for high metaphysical experiences with things which were low. And yet one could notice a fundamental difference between the linguistic lows inscribed in the correspondence pact, and that which existed based on the novel pact. In the case of literary works, Witkacy tried to justify "vulgarity" not only to his readers, but also to his wife and himself. Yet his entire correspondence with Jadwiga only proved that he utilised the low constantly, and he did not conceal it underneath metaphysics. He often described the condition of his "spirit" through frenzied, almost spewing carnality. So, one could read in Witkacy's letters that he was "breaking into chunks" ${ }^{81}$ due to his impatience and inability to express that which he wanted to express, that "the gut is rising to his throat" 82 , or that "everything is escaping through the sides." ${ }^{\prime 3}$ In one of his letters, he compared himself to a urinal, into which anyone can pee until his ear breaks off. ${ }^{84} \mathrm{He}$ also found

${ }^{77}$ E. Vila-Matas, Krótka historia literatury przenośnej, trans. J. Karasek, Wydawnictwo Literackie MUZA SA, Warsaw 2007, p. 103. [English version translated from Polish].

${ }^{78}$ Ibid., p. 103.

${ }^{79}$ S.I. Witkiewicz, Ld亡 (1923-1927), pp. 104-105.

${ }^{80}$ Idem, Ldż (1923-1927), p. 117.

${ }^{81}$ Idem, $L d \dot{z}$ (1928-1931), p. 89.

${ }^{82}$ Ibid., p. 154.

${ }^{83}$ Ibid., p. 144.

${ }^{84}$ Idem, Ldż (1932-1935), p. 128. 
joy in creating carnal charades, e.g. Benis - penis $^{85}$, genitals - genietals. ${ }^{86}$ As a result, the charades, which were always considered a low kind of joke, became jokes touching the very bottom of earthly existence. As everyone knows, Witkacy officially fought against "jokers". Bocheński posited that each remark about them "ends in a reference to an image of carnality, as Witkacy juxtaposed the French lightness with carnival explicitness." ${ }^{" 77}$ And yet the artist would like:

(...) to find for humour a place within the modernist hierarchy of values (...) $\mathrm{He}$ also wanted to find a justified place, though marginal for an artist - jester within the hierarchy of artistic attitudes. (...) Thus Witkacy experienced the basic problem of post-Enlightenment art: the problem with accepting the carnival tradition. He perceived the lewd, ludic, earthly, and anarchising laughter as a foreign and destructive element $(\ldots)^{88}$

Micińska argued that Witkacy's letters were art as he was an artist par excellence, and he turned everything into art. "One could only ask about the significance of his specific achievements (...)" ${ }^{\prime 99}$ If one considers the significance of the letters, they should be classified as metaphorical literature - light and devoid of any "relevance" understood in modernist terms. Though being so different from Dadaists and surrealists, who intentionally nurtured randomness, involuntarily, specifically in his letters to his wife, Witkacy also created "metaphorical literature."

The very material of a letter is already random. Witkacy, according to Degler:

(...) rarely used letter paper. He usually utilised that which he had at his disposal at a given moment. Thus he wrote on some scraps, torn off sheets, on the back side of his manuscript or typescript, on official letters, bills, laundry receipts, cards from the calendar, as well as (...) on the back of letters addressed to him $(\ldots)^{90}$

Therefore, Witkacy's "letter-writing"91 was, in fact, a form of "recycling". ${ }^{2}$ One could notice some similarities with Schwitters, who used "the waste of the civilisation discovered at random, (...) items which indicated destruction and

${ }^{85}$ Idem, (1936-1939), p. 15.

${ }^{86}$ Idem, Lḋ (1932-1935), p. 89.

${ }^{87}$ T. Bocheński, Czarny humor w twórczości Witkacego, Gombrowicza, Schulza. Lata trzydzieste, Towarzystwo Autorów i Wydawców Prac Naukowych Universitas, Krakow 2005, p. 42.

${ }^{88}$ Ibid., p. 56.

${ }^{89}$ A. Micińska, Istnienie poszczególne..., pp. 168-269.

${ }^{90}$ J. Degler, Witkacego portret wielokrotny..., p. 314. [English version translated from Polish].

${ }^{91}$ A term used by J. Degler in Witkacego portret wielokrotny..., pp. 311, 312, 558.

92 T. Bocheński, Dwa teatry Witkacego, p. 212. 
decay." ${ }^{93}$ Collecting was then, of course, becoming a fashion among surrealists and Dadaists. Yet Schwitters created his major work, Merzbau, on the margins of official works. As Hans Richter once noted, the column was actually "a composition of various grooves". ${ }^{94}$ Schwitters filled them with special edgings of existence - that which is unimportant and private. "It was not any old sculpture, but a living changing every day documentary image of Schwitters himself as well as his friends." ${ }^{95}$ The work had one particular flaw: it was not mobile. To his despair, Schwitters left it in 1937 as prey to the German bombs, and he "never forgave the Nazis for destroying his opus magnum (...), a work with which he identified more than with any other of his creations." ${ }^{96}$ Unlike Schwitters, Witkacy did not treat that which was degenerated and marginal as something deeply significant. He knew that art degenerates, so he countered that degeneration with his pure art. Yet on the side, in unofficial circulation, he allowed himself to create degenerated art.

"The character and the script of his handwriting indicate that (...) he wrote hurriedly, fervently, without any major consideration for any correctness of his style," argued Degler. The spontaneity of letters bears something of the surrealist method of psychological automatism - it reveals 'the actual functioning of thoughts' (...) that which is real, authentic, and honest ${ }^{97}$. The analogy between letters and the concept of a sack-novel, referenced by Micińska, seems accurate as Witkacy did, in fact, put his confessions to his wife into one sack. Thus the letters are filled with random series of associations. For example, from begging Jadwiga not to leave him, Witkacy transitioned to informing her that he had sprained his leg for the second time, only to remark that "there ain't no snow". 98

To reveal that which is real, authentic, and honest, one must become free of the control of the great censor - the mind. In his Dziennik poufny, Baudelaire concluded that "the more man practices fine arts, the less he screws. The division into the spirit and boorishness is becoming increasing evident." 99 Such a division is present in Witkacy's correspondence. Apart from private letters, he also wrote, from the heights of his spirit, philosophical letters, "entire treatises, dissertations, and polemics, which he exchanged with the major philosophers of his time: Hans Cornelius, Roman Ingarden, Jan Leszczyński, Tadeusz Kotarbiński, Władysław

${ }^{93}$ H. Richter, Dadaizm. Sztuka i antysztuka, trans. J. Buras, Wydawnictwa Artystyczne i Filmowe, Warsaw 1983, p. 22. [English version translated from Polish].

94 Ibid., p. 254.

95 Ibid., p. 254.

${ }^{96}$ Ibid., p. 256.

${ }^{97}$ K. Janicka, Światopogląd surrealizmu. Jego założenia i konsekwencje dla teorii i twórczości i teorii sztuki, Wydawnictwa Artystyczne i Filmowe, Warsaw 1985, p. 178. [English version translated from Polish].

${ }^{98}$ S.I. Witkiewicz, Ldż (1923-1927), p. 214.

${ }^{99}$ Ch. Baudelaire, op. cit., p. 291. 
Tatarkiewicz, et al." ${ }^{100}$. With a polemic with some philosopher in mind, Witkacy stated in a letter to his wife: "you have no idea what kind of an answer I banged out to him to that. What a shame I don't have a secretary who would copy my letters." 101 A secretary should, therefore, censor that which is low, carnal, and copy that which is lofty, and which is a construct of the mind. Because Witkacy should survive as a work of art, not as man.

In one of his letters, the artist explained, though not to his wife, rather to himself, why he deliberated on what he had eaten for dinner, and on the texture of his faeces - i.e. on that which according to his category falls under " 1 st $\mathrm{cl}$ [ass] real issues"102: "because, philosophically speaking, many interesting facts, but none for you, Ninek." 103 Jadwiga reminisced that Witkacy incessantly accused her of no interest in philosophy. So he criticised his wife just like he did the rest of society. In an interview for the Krakow-based daily Glos Narodu, he complained about the audience, which "is less and less capable of understanding something that transcends railway-action romantic stories." 104 In other words, the audience was less and less capable of experiencing transgressive metaphysical emotions, and was content with remaining in the slime of commonness. Witkacy rebuked clown-writers who corrupted art, and in turn the society. He displayed the typical attitude of a Westerner, which, according to Maffesoli, consisted of criticising. Criticising "is a keyword summarising an approach to the world, specific for the ego of an individual dominating nature, specific for a rational predator, who tries to change, construct, and analyse everything." ${ }^{105}$ However, when the artist did not have to save the world, he immersed himself in life's content on the margin of that which was official. As Jadwiga reminisced:

(...) Staś would eagerly read travel books (...), various vies romances, even detective novels. (...) whenever a daily paper published a novel in instalments, we would read it together, having a lot of joy in such a - usually poor read; e.g. it was Iwonka by J. German. When I was away from Zakopane, (...) Staś would send me in the letters the instalments of such novels with his remarks - that was wonderfully amusing. ${ }^{106}$

In the summer of 1931, he expressed admiration at a novel by an English writer Rufus Frederick King: “(...) are you keeping King's novel? If so, that' excellent,

${ }^{100}$ A. Micińska, Istnienie poszczególne..., p. 269.

101 S.I. Witkiewicz, Ldi (1932-1935), p. 222.

102 Idem, $L d \dot{z}$ (1923-1927), p. 20.

${ }^{103}$ Idem, Ldż (1936-1939), p. 269.

${ }^{104}$ Idem , Ldż (1928-1931), p. 299.

${ }^{105}$ M. Maffesoli, Rytm życia. Wariacje na temat świata wyobraźni ponowoczesnej, trans. A. Karpowicz, Zakład Wydawniczy Nomos, Krakow 2012, p. 36. [English version translated from Polish].

106 J. Witkiewiczowa, Wspomnienia o Stanisławie Ignacym Witkiewiczu in: S.I. Witkiewicz, Ldż (1936-1939), p. 600. 
because it's good," 107 he wrote to his wife on 11 August 1931. Two weeks later he inquired: "How did you like King's novel?"'108 Jadwiga was apparently more critical about the book than her husband. In response to a suggestion about the simplicity of some solutions used by the author of the crime story, Witkacy did admit: "as for King, it is absolutely just, but that is the flaw of all crime novels that they are deficient in such a way," ${ }^{109}$ yet it did not in any way decrease his reading enthusiasm. Already in the following sentence he added: "immediately send back the whole King." 110 In a letter of 22 March 1937, he confessed to his wife to reading for pleasure as if he was confessing some spiritual crime against intellectual work: "I haven't even started working on philosophy, and I'm reading with great pleasure a novel by Benoit, and some crime story by Hume." ${ }^{111}$ He immediate found something to redeem himself with: "I have the right after that visit to W." 112 So was Witkacy really lamenting the fact that he could not engage with his wife in a discussion of a philosophical nature? Rather with joy of communicating with her through that which is low: low art, and low carnality. His wife was a person thanks to whom he could touch the filthy reality without any metaphysical "interest".

The editors of Witkacy's letters, who together managed to overcome the seven circles of editorial hell ${ }^{113}$, confessed to Witkacy trying to soothe the indubitable suffering of his soul. It is difficult to trust Micińska's assumption that Witkacy could have changed his mind from beyond, and ensured the survival of his letters. In any way, as the researcher stated:

today, we are the fortunate heirs to a document, which not only does not discredit the author, but even the contrary: it constitutes one of the most fascinating works of literature of that epoch, if not the most fascinating work of the author of Szewcy and Nienasycenie. ${ }^{114}$

Degler expressed a similar position:

(...) Witkacy's entire correspondence, his letters to his wife in particular, were undoubtedly his great, though unintentional, work (...) Who knows whether upon being published in its entirety, it will not overshadow his output... ${ }^{115}$

${ }^{107}$ S.I. Witkiewicz, Ldz (1928-1931), p. 237.

${ }^{108}$ Ibid., p. 246.

${ }^{109}$ Ibid., p. 267.

110 Ibid.

${ }^{111}$ Idem, Ldż (1936-1939), p. 102.

112 Ibid.

${ }^{113}$ Phrase used by A. Micińska, v. J. Degler: "'Piekło edytora', czyli o listach Witkacego do żony", Przestrzenie teorii 2010, issue 14. [English version translated from Polish].

${ }^{114}$ S.I. Witkiewicz, $L d \dot{z}$ (1923-1928), p. 449.

115 J. Degler, Witkacego portret wielokrotny..., p. 333. 
Interestingly enough, though Micińska and Degler were inclined to consider Witkacy's letters as his greatest work, they had a dilemma whether to publish them in their entirety. As Degler stated:

we had considered removing some of the letters or omitting certain fragments, e.g. the one in which Witkacy complained that in the forest a horse-fly bit his vitals, and he begged Nina to come and soothe his pain. ${ }^{116}$ We decided we will not censor anything. ${ }^{117}$

The idea with the censorship proved the instrumental approach towards correspondence. Micińska and Degler wanted to see in the letters mainly those elements, which deconstructed Witkacy's negative legend, while they ousted others, just like Witkacy did, to the fringes. Yet censoring the history of an uncensoring mind would not even be possible!

By liberating himself from the influence of the censor, Witkacy did not, however, feel such pleasure as Dadaists or surrealists. When he "betrayed" Pure Form, he felt remorse, and constantly tried to justify his "betrayals".

Surrealists and Dadaists not only fostered randomness in their art. In life, they sought involuntary peculiarity, which would confirm that existence has a similar structure as their creative imagination, and their avant-garde artistic concepts, "magie circonstancielle" in particular. Adam Ważyk wrote that

in the surrealists' vision, the world is full of randomness in the first instance; we do not know the second one, the world in its entirety is repulsive, but it does include some tempting things - strange encounters and travels (...) Exceptional phenomena with an after taste of wonder hide within the entire matter of everyday life, just like in Apollinaire's works, where wonder, considered based on either of its meanings, has always had a low nature. ${ }^{118}$

Witkacy rather used his "grey matter" for processing "grey reality". In life, just like in art, he planned to use chance. In the memories of various persons, he existed as the director of a fantastic theatre of existence. According to Płomieński, Witkacy:

\footnotetext{
${ }^{116}$ A. Augustyn, J. Degler, “Oszalej i wyjdź za mnie” in: http://www.wysokieobcasy.pl/wysokie- obcasy/1,96856,9865307,Witkacy_oszalej_i_wyjdz_za_mnie.html?disableRedirects=true (accessed on 12.12.2015).

117 A. Augustyn, J. Degler, “75 lat po śmierci Witkacego. Kim był naprawdę?”, Gazeta Wyborcza, 13.09.2014, http://wyborcza.pl/magazyn/1,140736,16633912,75_lat_po_smierci_Witkacego_Kim_byl_naprawde_html? disableRedirects=true (accessed on 12.12.2015).

${ }^{118}$ A. Ważyk, Surrealizm. Teoria i praktyka literacka. Antologia, trans. A. Ważyk, Czytelnik, Warsaw 1976, pp. 16-17. [English version translated from Polish].
} 
often constructed unbelievable scenes, in which he assigned his friends or close acquaintances strange roles, he invented and planned social encounters catching with uncontrollable satisfaction punchlines unthinkable in a natural mode of life, and wallowed experiencing internal delight; he possessed a truly Shakespearean imagination, and he bent the rigid material of life to its vivid frolics. ${ }^{119}$

The social meetings arranged by him were artistic compositions displaying the highest levels of disharmony. Thus for Witkacy, the most successful ones were the meeting of Ingarden with a sports personality "who tapped the renowned scientist on his knee (...), and bladdering without any reservations 'You're talking rubbish"' 120 , or of Nadezdha Drucka, with a philosophy researcher, and a prostitute. Surely when arranging those meetings, he experienced pleasure as the director of Pure Form, who connected various random elements into one whole.

When, however, random events happened to Witkacy, he was terrified; a fact which was best proved by his superstitiousness. In a letter to Bronisław Malinowski of 1914, he listed sixteen synchronicities, which condensed into a superstition regarding the hour twenty to ten, which carried a fatalistic significance in his life. He also believed that the number seven and a nine of hearts brought him bad luck. In his letters to his wife, he often expressed his superstitiousness, and one unfortunate synchronicity troubled him the most. On 04 April 1937 he wrote: "there appeared the Mysterious Cobbler from my dreams and reality - together 20 to 10 , the 9 of hearts constituted a bull's sequence of bad omens." ${ }^{.121}$ In the following letter, he explained in more detail: "here goes: 20 to 10 (2 Mar), 9 of hearts (3 Mar), Bundykowa grabbed the hand of Dieu du ventre. Death of Karol S[zymanowski]. The demolition of the house of Ślimak. The appearance of the Mysterious Cobbler. That's enough. What's next?"122. He calculated: "until 2 May this terrible period will last, and I have escaped the Mysterious Cobbler twice in a row in the street, which could have a terrible rebound." ${ }^{23}$ Meeting the Mysterious Cobbler was the unluckiest element of that exceptionally unfortunate, in Witkacy's view, synchronicity. Though it is not difficult for one to imagine what an impression it would make on surrealists. Suffice to mention Breton's Nadja, a work the composition of which is dominated by random and rare encounters. The story is set in Paris, in the streets of which almost each day around noon he meets Nadja. Breton presented that synchronicity as the intervention of wonder in

119 Stanisław Ignacy Witkiewicz: człowiek i twórca. Księga pamiątkowa, T. Kotarbiński, J. Płomieński (ed.), Państwowy Instytut Wydawniczy, Warsaw 1957 p. 194. [English version translated from Polish].

${ }^{120}$ Ibid., p. 201.

${ }^{121}$ S.I. Witkiewicz, Ld亡 (1936-1939), pp. 107-108.

122 Ibid., p. 108.

${ }^{123}$ Ibid., p. 119. 
reality. It was the contrary for Witkacy: he was afraid of that which happened, and which, basically, was a reflection of the Mystery of Existence. Bocheński in an article Drogi do Tajemnicy ${ }^{124}$ discussed Witkacy's methods of evoking it. Those included: the previously-mentioned intensity of experiences, solitary mountain hikes, or conditions of great exhaustion. Those methods resulted from the modernist conviction about the necessity to prepare oneself for transgressive experiences through tormenting one's carnality. Yet Witkacy increased his control over evoking the Mystery to such an extent that it became ridiculous. As Andrzej Gass reminisced:

in Ewa Dzieduszycka's dairies (...), there are remarks about Witkacy as an extremely gifted organiser of spiritism meetings. Only through bad luck he was once caught manipulating the strings he used to evoke various otherworldly signals. ${ }^{125}$

Thus, wonder had for Witkacy, unlike for Dadaists or surrealists, an elevated and not low nature. Noticing that he was not high enough above that which was earthly, the artist wrote to his wife: "I need to break away from reality." 126 In another instance, he informed her: "I'm constructing myself into another dimension." ${ }^{27}$ When he came to the conclusion that he could not pull his life up to "a little higher level"128, he considered it finished.

One of the methods of elevating oneself to spiritual heights was isolation from the lows innate in other people. On 16 October 1923, he informed his wife: "I'm implementing total isolation"129, on 20 April 1926, he wrote: "I'm isolating myself as much as I can." ${ }^{130}$ Of course, one could doubt that, as in the following sentence he added: "but I went with the Rytards and Miskuper to the Albertis." 131 He repeated his pledge on 3 March 1927: "people are terrible beasts. I'm isolating myself even further." ${ }^{32}$ On 6 February 1929: "I'm beginning to fend people off with a spiked mask." 133 On 2 August 1929: "human stupidity is so huge that only a mask, and isolation can help to live." ${ }^{134}$ One element of the isolation from the external world were red rings hung on the door barring

${ }^{124}$ T. Bocheński, Witkacy i reszta świata, Wydawnictwo Officyna, Lodz 2010, pp. 49-50. [English version translated from Polish].

${ }^{125}$ A. Gass, "Spotkanie z duchem”, Sztuka 1985, issue 2/3 [English version translated from Polish].

126 S.I. Witkiewicz, Ldz (1928-1931), p. 153.

${ }^{127}$ Idem, $L d \dot{z}$ (1932-1935), p. 146.

${ }^{128}$ Idem, $L d \dot{z}$ (1936-1939), p. 141.

${ }^{129}$ Idem, Ldż (1923-1927), p. 34.

${ }^{130}$ Ibid., p. 89.

${ }^{131}$ Ibid.

132 Ibid., pp. 88-89.

${ }^{133}$ Idem, Ldz (1932-1935), p. 61.

${ }^{134}$ Ibid., p. 125. 
anyone from entering the artist's room. Witkacy himself considered them as a "defence system": "I'm hardly seeing anyone. The red ring on the wardrobe protects against visits." 135

The system did not always prove successful, though. The external world sometimes literally broke into Witkacy's spiritual enclave. The artist, outraged, informed his wife: "today, having disregarded the [red] ring, Malczewska tore into my place, and told me uncanny things about her quarrels with Dominik." 136 In another letter, he wrote: "it's v. difficult and boring in the world even though the weather's nice. Each moment of my life is a titanic struggle with the flooding filth. And nothing pleasant comes from anywhere. Is it worth living in such a condition?"137 Witkacy's being-in-the-world tactics consisting of an incessant struggle with filth included a certain contradiction. He did not notice that when he did not allow reality to reach him, nothing could "come" to him.

Nonetheless, his letters to his wife were, most of all, a record of his struggle with himself. They could be read as an unrelenting attempt at creating some "invariant". In Nienasycenie, the author instructed his protagonist:

“(...) how can you construct yourself in such circumstances?” thought Genezyp not understanding that precisely that constructing should be independent of all conditions, it should be an "invariant". 138

Witkacy, in fact, wanted not only to create Pure Form works, but also to conduct self-creation according to his principle, as if to transform into one of the characters from his plays. The term self-create resonates with the high modernist tone - of a conviction that one can create oneself using intellectual powers, and in turn liberate oneself from everything which is irrational and random, i.e. impure, gutty, low, and earthly. Throughout his output, Witkacy struggled with "dwindling reality"139, while in his letters: with his own "dwindling": "I will start working tomorrow so as not to dwindle," 140 he informed Jadwiga in one of his letters. Dwindling was one of the metaphors of the lack of internal organisation introduced by intellect. ${ }^{141}$ When Witkacy managed to assign his life intellectual organisation, he sometimes used the metaphor of a bull or buffalo, e.g.:

135 Ibid., p. 94.

${ }^{136}$ Ibid., p. 124.

${ }^{137}$ Idem, Ld亡 (1923-1927), p. 74.

${ }^{138}$ Idem, Nienasycenie, p. 179.

139 T. Bocheński, Witkacy - ciało, A multi-media project of the Institute of Literary Research entitled Sensualność w kulturze polskiej, http://www.sensualnosc.ibl.waw.pl/pl/articles/witkacy-cialo-183/ (accessed on: 10.11.2015).

${ }^{140}$ S.I. Witkiewicz, Ldż (1932-1935), p. 258.

${ }^{141}$ Ibid. 
"I've been working all day like a buffalo"142, or: "my bull state, the hell with it, continues." 143

Genezyp knew that self-creation consists of becoming independent of that which is external. Witkacy knew that, but that knowledge proved insufficient: "it is doubtful whether I will be able to create the $3^{\text {rd }}$ epoch. Unfortunately, that depends on external conditions, not only on the system of navel-liver powers."'144 By tracing the letters, one could notice that the most pronounced crisis of the modern subject that wished to create himself was the break-up with Czesława Oknińska-Korzeniowska in 1938.

Stefan Okołowicz in an article entitled Nieznana kobieta $w$ zyciu Witkacego noted that the origins of the break-up with Czesia lay in Witkiewicz's theatre of existence, in a drama listed under various names: Afera z fryzjerem [Scandal with the Barber], Afera Pinno [Pinno Scandal], or Dossier Pinno [Pinno Dossier]. It, of course, referred to his affair with Maria Zarotyńska, which he started in 1936. Witkacy did not play his drama out only in the private theatre. It was irrelevant that he created it out of filthy intimacy since he "angelised" those elements into a wonderful art of Pure Form. Alfred Łaszkowski, who interviewed Witkacy, reminisced that at the end the artist glanced at his watch anxiously and said:

(...) I stopped shaving by myself some time ago. I go every day to put my neck under the blade of a man from whom I stole a fiancée. If only he put the razor a bit deeper, I would be gone in five minutes. An obvious thing: he has a terrible desire to do that, and I'm watching it in the mirror as that intent grows, and I'm experiencing a unique satisfaction, one which is the highest and cannot be substituted by anything. (...) But as I tighten my relationship with his darling, the razor strokes become increasingly dynamic. Remember this as any moment now I might drop dead with a slit throat in an air of perfect orchestration of the mechanics of an accident. ${ }^{145}$

Okołowicz noted that gradually the 'Pinno Scandal' began to transform into the so-called 'Marysia problem'. ${ }^{46}$ The Pure Form drama seemed to continue to lose its form, and change back into a regular life drama. The final fall into life occurred when Witkacy parted with Czesia in mid-March 1938. About the significance of that break-up among a series of many break-ups, Witkacy learnt when Czesia sent back to him an 80-kilogram package of everything she had ever received from him. The situation seemed more complex, though, than it was presented by Okołowicz, i.e. that the "Marysia problem" led to the parting with

\footnotetext{
${ }^{142}$ Ibid., p. 263.

${ }^{143}$ Idem, Ldz (1935-1939), p. 102.

${ }^{144}$ Idem, Ldż (1923-1927), p. 55.

145 S. Okołowicz, op. cit., p. 255.

${ }^{146}$ Ibid., p. 257.
} 
Czesia, while the parting with Czesia caused a depression, which resulted in the artist's suicide the following year. In a letter to his wife, Witkacy concluded: "it's not only the fact of my losing her, but this has revealed my entire internal misery"147. When he wrote: "something snapped inside me with that 80-kilogram package" 148 , he precisely meant his internal structure, which he tried using his mind to create as an invariant. The innocent "Pinno scandal", from which he created the Pure Form theatre, started to slip out of the control of his mind. "Marysia problem' the so-called," he wrote to his wife on 9 February 1938, "is something completely irrational, and I'm absolutely fed up with it too. I would like to start a N. L. [New Life], but I lack the foundation i n m e." ${ }^{149}$ Despite his efforts, two months later the situation remained the same: "my condition is not good, as I still do not have in me any general foundation for fighting this terrible blow to my mug (...)"150 Similar, though less serious, self-creative breakdowns had already afflicted Witkacy earlier due to his break-ups with Czesia. In 1931, Witkacy complained to Jadwiga:

oh well - it seems she has broken up with me for good. Then à propos that (...) I need to reconstruct myself from the bottom and the inside, (...) I need to find me some invariant, which would enable me to halt everything. (...) I am not an artist, and it's difficult for me to become one - that is the worst. When I was that, I suffered through even the worst things basing on it. Now I don't have that foundation. ${ }^{151}$

The gesture of not considering himself an artist was, of course, only a statement. Witkacy did not express his conviction, but his fear that he had stopped being one who could sense the cosmic reflection of the invariability of existence.

Nietzsche argued that "to create one's own mind means to create one's own language, and to let the limits of our mind be defined by a language left behind by other human beings." 152 The fact that Witkacy experienced the "inherited" language as being limiting was posited by Magdalena Nowotny-Szybistowa in a book entitled Osobliwości leksykalne w języku Stanisława Ignacego Witkiewicza. She wrote that:

a strong conviction of the wearing out of the components of the existing culture, including the elements of the language, was a starting point for his semantic opera-

\footnotetext{
${ }^{147}$ S.I. Witkiewicz, Ldz (1936-1939), pp. 219-223.

148 Ibid., p. 223.

${ }^{149}$ Ibid., p. 188.

${ }^{150}$ Ibid., p. 229.

${ }^{151}$ S.I. Witkiewicz, Ldz (1928-1932), p. 271.

${ }^{152}$ As cited in: R. Rorty, Przygodność, ironia i solidarność, trans. W.J. Popowski, Wydawnictwo Spacja, Warsaw 1996, p. 51. [English version translated from Polish]
} 
tions. Witkacy was convinced that by accepting the linguistic inheritance, we are condemned to automatic and passive use of those elements (...) When building a work of literature, one must be aware of the fact that one builds it from culturally drained units. One must also prevent those automatic reactions as they make any authentic literary creation impossible. (...) The use of old elements must be done in such a way as to indicate the distance between the creator and the material they are using. In other words, one can use some traditional components, yet that must be done in stylistic quotation marks to mark an author's attitude to the semantic load known to them. ${ }^{153}$

Upon analysing the words which Witkacy most often placed between inverted commas, Magdalena Nowotny-Szybistowa concluded that they belonged to the colloquial register of Polish, i.e.:

they reflected the tendency of the contemporary culture in its mass and hateful, according to Witkacy, version, remaining in line with the style of the cinema, newspapers, and the radio. (...) by fighting against such words, the author expressed his opposition to the standardisation of the language in the name of individuality. ${ }^{154}$

Linguistic standardisation was also, according to Witkacy, combated by the philosophical discourse, with which in the 1930s the artist increasingly often substituted the language of art. It was actually through philosophy that he tried to handle the "Marysia problem": "tomorrow I'm starting with logic with full force. I need to overcome this hysteria," $" 155$ he declared in one of his letters. Despite those efforts, Witkacy's biography more and more resembled a story in a romantic novel. After parting with Czesia, he wrote to his wife: "but here there's something else that I 'cannot live without' her, as they say in novels - I cannot see anything in front of me without her. What should I do? I will try to vanquish myself, provided there will be no make up - but that will be terribly difficult." ${ }^{156}$ In another letter, he wrote: "on my part the break up with $\mathrm{Cz}$ [esia], katzenjammer, and thousands of reasons. Thank you very much for your letter, which lifted me 'in my distress'." 157 Using the quotation marks, according to Nowotny-Szybistowa's proposal, which expresses metalinguistic detachment, as if Witkacy tried to defend himself from the trivialised language of romantic literature, in which he absolutely did not wish to speak. He tried to avert his fall from a modern subject into a social object, and his prayers for an invariant in the letters to his wife intensified.

\footnotetext{
${ }^{153}$ M. Nowotny-Szybistowa, Osobliwości leksykalne w języku Stanisława Ignacego Witkiewicza, Zakład Narodowy im. Ossolińskich, Wroclaw 1973, p. 12

154 Ibid., p. 19.

155 S.I. Witkiewicz, Ldz (1936-1939), p. 159.

${ }^{156}$ Idem, Ldż (1932-1935), p. 253.

${ }^{157}$ Idem, Ldż (1936-1939), p. 207.
} 
Quoting Rimbaud's famous words: "I is another"158, one could say that Witkacy fought the other inside him. And yet the sentimental conventional other spoke in crisis situations through the modern subject as a model of authenticity.

Witkacy's wife remained his only invariant. His supplication expressed in a letter to his wife: Hold me if you can ${ }^{159}$, I understand literally - the artist wished to find support in the spiritual bond between him and his wife in the situation of a loss of his internal intellectual structure. "I read your letter with tears in my eyes, that was how much your kindness moved me, but if someone really saw my condition, he would not be surprised by anything, and would allow me total freedom of action." ${ }^{160}$ Freedom which Witkacy, enclosed inside a melodrama structure, had already lost.

Sometimes, Witkacy, being bored with his biography, which he could not elevate to the level of Pure Form, span wild plans of detaching from it. "Everything bores me terribly, and I don't know if I won't leave for the tropics," 161 he stated in one of his letters. Those plans entailed his desire to experience illinx - "stupefaction caused by depending on fate."162 Breton mentioned what role that element played in Duchamp's life: "I saw (...) him doing astounding things: he flips a coin and says: "heads - I'm leaving for America tonight, tails - I'm staying in Paris." "163 Witkacy's idea should be considered, though, as completely virtual as his defining feature, as indicated by his biography, was his complete "irrelocationness". "I'm very tired with the life of a wanderer, and I'm dreaming of home," 164 he wrote to his wife from Królewska Huta. When staying in Krakow, he complained: "I wish to experience the peace of Zakopane very much." 165 For Witkacy, a solitary mountain hike was a feat. Though he considered it as one of the paths for experiencing the Mystery of Existence, he rarely chose to do that. That was indicated in a letter, in which he stressed that he hiked in the mountains alone as something extraordinary:

Yesterday, I went on a v. strange solitary hike. ${ }^{166}(\ldots)$ I woke up, and I went to Głog[owski] through Ant[ałówka] set for Czerw[one] Wierchy. And that pillock had a headache. So I went to Stachurska, but her leg hurt. So I took a dump in the forest

${ }^{158}$ A. Rimbaud, Korespondencja Artura Rimbaud, trans. J. Hartwig, A. Międzyrzecki, Spółdzielnia Wydawnicza „Czytelnik”, Warsaw 1970. [English version translated from Polish].

${ }^{159}$ S.I. Witkiewicz, Ldż (1936-1939), p. 223.

${ }^{160}$ Ibid., p. 238.

${ }^{161}$ Idem, Ldz (1932-1935), p. 30.

${ }^{162}$ R. Caillois, Gry i ludzie, trans. A. Tatarkiewicz, M. Żurowska, Oficyna Wydawnicza Volumen, Warsaw 1997, p. 71.

${ }^{163}$ C. Tomkins, op. cit., p. 227.

164 S.I. Witkiewicz, Ldż (1932-1935), p. 142.

165 Idem, Ldż (1936-1939), p. 190.

${ }^{166}$ Ibid., p. 69. 
near the road to Białe, and I went alone. It rained several times, but I had my windbreaker, and it was wonderful. ${ }^{167}$

The combination of taking a dump and feeling wonderful said a lot about the adult Witkacy. In time, his paths towards the Mystery were replaced by "the hellish shitty-farty adventures."168 For Witkacy, becoming a "Portrait Company" or a "Novel Company" was a decline. How much had the decline intensified when in 1932 Witkacy became, as he informed his wife in a letter, of course, a "shit Factory." 69 Being a "shit Factory", he produced works even lower than novels or portraits, e.g. Krytyka stosunków klozetowych na Anattówce w „wolnym” wierszu wyrażona ${ }^{170}$. Instead of new methods of processing reality, enabling him to construct a new "epoch of life", Witkacy invented "new methods of dump-taking"171, and soon his life transitioned into "a terrible epoch of red shit." 172 Previously, he focussed on "weighing" in a work of art pure and impure elements; the "shit Factory" focussed on calculating the percentage share of shitheads among its friends. ${ }^{173}$ "I am surrounded by a mob of enemies," ${ }^{174}$ concluded Witkacy noticing the masters and the servants: "all = one shit." ${ }^{175}$ Yet he himself proved to be the biggest "shithead". The struggle against the filth flooding in from everywhere must had seemed for Witkacy nonsensical after he had discovered endless deposits of filth in himself: "I'm shitting so terribly that if one collected it, it would form a pyramid of shit not much better than the Pyramid of Cheops, despite some looseness. I'm simply turning into a Baghdad-Antałówka pipeline. I don't understand where it is coming from, as I'm not [eating] that much, actually." 176 The spiritual aristocrat could not come to terms with his final demise. The struggle with shit was another chapter of the mock-heroic treatise recorded in his letters to his wife, in which "the titan fights against the triviality of the remainder of spirituality." 177 The chapter concluded in an image of a half-washed titan with shit-stained linen pants. ${ }^{178}$ That was also the image of an artist who tried to be

\footnotetext{
${ }^{167}$ Ibid., p. 70.

${ }^{168}$ Idem, Ldż (1932-1935), p. 21.

${ }^{169}$ Ibid., p. 13.

${ }^{170}$ Poza rzeczy-wistościa - wistość tych rzeczy jest nie z świata tego. Stanisława Ignacego Witkiewicza wiersze i rysunki, selection A. Micińska, U. Kenar, Wydawnictwo Literackie, Krakow 1977, pp. 112-113.

${ }^{171}$ S.I. Witkiewicz, $L d \dot{z}$ (1936-1939), p. 146.

172 Ibid., p. 203.

${ }^{173}$ Ibid., p. 122.

${ }^{174}$ Ibid., p. 272.

175 Ibid.

${ }^{176}$ Ibid., p. 195.

177 T. Bocheński, Dwa teatry Witkacego, p. 208.

${ }^{178}$ S.I. Witkiewicz, $L d \dot{z}$ (1936-1939), p. 160.
} 
modern yet involuntarily was anti-modern as it is commonly known that between the development of art, and the development of hygiene, there is a strong interrelation, in which dirt is a type of resistance against modernity. According to Marshall Berman, the elements of anti-modernity in modernism, i.e. an art which strived for originality and innovation, were of utmost importance. Witkacy, an artist from the provinces, who wished to become an artist fitting modern West European art, and who tailored his theory of Pure Form to that, did not express his anti-modernist opposition directly. It was reflected in creating forms discredited from the point of view of modernist art, and in Witkacy's theory - low, carnal, trivial, and autobiographic forms. Thus in his letters to his wife, Witkacy found a peculiar area of freedom - freedom of self-discreditation.

\section{Bibliography}

\section{Subject bibliography. Works by S.I. Witkiewicz}

Jedyne wyjście, Anna Micińska (ed.), Państwowy Instytut Wydawniczy, Warsaw 1993.

Listy I, Tomasz Pawlak (ed.), Państwowy Instytut Wydawniczy, Warsaw 2013.

Listy do żony (1923-1927), prepared by Anna Micińska, Janusz Degler (ed.), Państwowy Instytut Wydawniczy, Warsaw 2005.

Listy do żony (1928-1931), prepared by Anna Micińska, Janusz Degler (ed.), Państwowy Instytut Wydawniczy, Warsaw 2007.

Listy do żony (1932-1935), prepared by Anna Micińska, Janusz Degler (ed.), Państwowy Instytut Wydawniczy, Warsaw 2010.

Listy do żony (1936-1939), prepared by Anna Micińska, Janusz Degler (ed.), Państwowy Instytut Wydawniczy, Warsaw 2012.

Narkotyki, Niemyte dusze, Anna Micińska (ed.), Państwowy Instytut Wydawniczy, Warsaw 1993. Nienasycenie, Łukasz Front (ed.), Wydawnictwo Marek Derewiecki, Kęty 2013.

O czystej formie i inne pisma o sztuce, Janusz Degler (ed.), Państwowy Instytut Wydawniczy, Warsaw 2003.

Pisma krytyczne i publicystyczne, Janusz Degler (ed.), Państwowy Instytut Wydawniczy, Warsaw 2015.

Poza rzeczy-wistościq - wistość tych rzeczy jest nie z świata tego. Stanisława Ignacego Witkiewicza wiersze i rysunki, selection Anna Micińska and Urszula Kenar, Wydawnictwo Literackie, Krakow 1977.

Pożegnanie jesieni, Elżbieta Zarych, Iwona Misiak (eds.), Wydawnictwo Zielona Sowa, Krakow 2010.

\section{Object bibliography}

Augustyn Aneta, Degler Janusz, Oszalej i wyjdź za mnie, http://www.wysokieobcasy.pl/wysokie -obcasy/1,96856,9865307,Witkacy_oszalej_i_wyjdz_za_mnie.html?disableRedirects=true (accessed on 12.12.2015).

Augustyn Aneta, Degler Janusz, 75 lat po śmierci Witkacego. Kim byt naprawdę? Gazeta Wybor$c z a, 13$ September 2014, http://wyborcza.pl/magazyn/1,140736,16633912,75_lat_po_smierci_Witkacego__Kim_byl_naprawde_html?disableRedirects=true (accessed on 12.12.2015). 
Baudelaire Charles, Sztuka romantyczna. Dzienniki poufne, trans. and editing Andrzej Kijowski, Spółdzielnia Wydawnicza „Czytelnik”, Warsaw 1971.

Berman Marshall, Wszystko, co stałe, rozplywa się w powietrzu. Rzecz o doświadczeniu nowoczesności, trans. Marcin Szuster, Towarzystwo Autorów i Wydawców Prac Naukowych Universitas, Krakow 2006.

Bocheński Tomasz, Czarny humor w twórczości Witkacego, Gombrowicza, Schulza. Lata trzydzieste, Towarzystwo Autorów i Wydawców Prac Naukowych Universitas, Krakow 2005.

Bocheński Tomasz, "Dwa teatry Witkacego", Napis. Pismo poświęcone literaturze okolicznościowej 2012, XVIII, pp. 207-216.

Bocheński Tomasz, O pożądaniu u Witkacego, in: WITKACY 2014: co jeszcze jest do odkrycia? Materiały międzynarodowej konferencji naukowej z okazji 75. rocznicy śmierci Stanisława Ignacego Witkiewicza Stupsk, 17-20 września 2014, Janusz Degler (ed.), Muzeum Pomorza Środkowego w Słupsku, Słupsk 2016, p. 127-137.

Bocheński Tomasz, Powieści Witkacego. Sztuka i mistyfikacja, Wydawnictwo Uniwersytetu Łódzkiego, Lodz 1995.

Bocheński Tomasz, Witkacy i reszta świata, Wydawnictwo Officyna, Lodz 2010.

Bocheński Tomasz, Witkacy - ciało, A multi-media project by the Institute of Literary Research entitled Sensualność w kulturze polskiej, http://www.sensualnosc.ibl.waw.pl/pl/articles/witkacy-cialo-183/ (accessed on 10.11.2015).

Błoński Jan, Forma, śmiech i rzeczy ostateczne. Studia o Gombrowiczu, Towarzystwo Autorów i Wydawców Prac Naukowych Universitas, Krakow 2003.

Breton André, Nadja, trans. Józef Waczków, Oficyna Literacka, Krakow 1993.

Caillois Roger, Gry i ludzie, trans. Anna Tatarkiewicz, Maria Żurowska, Oficyna Wydawnicza Volumen, Warsaw 1997.

Czermińska Małgorzata, Autobiografia i powieść czyli pisarz i jego postacie, Wydawnictwo Morskie, Gdansk 1987.

Degler Janusz, "'Piekło edytora', czyli o listach Witkacego do żony”, Przestrzenie teorii 2010, issue 14 , pp. 13-32.

Degler Janusz, Witkacego portret wielokrotny. Szkice i materiaty do biografii (1918-1939), Państwowy Instytut Wydawniczy, Warsaw 2014.

Dubiński Krzysztof, Wojna Witkacego, czyli kumbol w galifetach, Wydawnictwo Iskry, Warsaw 2015.

Gass Andrzej, “Spotkanie z duchem”, Sztuka 1985, issue 2/3, pp. 56-57, 86-87.

Gombrowicz Witold, Dzienniki 1957-1961, Jan Błoński (ed.), Wydawnictwo Literackie, KrakowWroclaw 1986.

Janicka Krystyna, Światopogląd surrealizmu. Jego założenia i konsekwencje dla teorii i twórczości i teorii sztuki, Wydawnictwa Artystyczne i Filmowe, Warsaw 1985.

Jarzębski Jerzy, Podglądanie Gombrowicza, Wydawnictwo Literackie, Krakow 2000.

Leiris Michel, Wiek męski wraz z rozprawa literatura a tauromachia, trans. Teresa Błońska and Jan Błoński, afterword Jan Błoński, Państwowy Instytut Wydawniczy, Warsaw 1972.

Maffesoli Michel, Rytm życia. Wariacje na temat świata wyobraźni ponowoczesnej, trans. Agnieszka Karpowicz, Zakład Wydawniczy Nomos, Krakow 2012.

Márai Sándor, Księga ziól, trans. Feliks Netz, Spółdzielnia Wydawnicza „Czytelnik”, Warsaw 2011. 
Micińska Anna, Istnienie poszczególne: Stanisław Ignacy Witkiewicz, Janusz Degler (ed.), Wydawnictwo Dolnośląskie, Wroclaw 2003.

Nowotny-Szybistowa Magdalena, Osobliwości leksykalne w języku Stanisława Ignacego Witkiewicza, Zakład Narodowy im. Ossolińskich, Wroclaw 1973.

Okołowicz Stefan, "Nieznana kobieta w życiu Witkacego. Listy Stanisława Ignacego Witkiewicza do Marii Zarotyńskiej” in: Materiały sesji poświęconej Stanisławowi Ignacemu Witkiewiczowi w 60. rocznicę śmierci, Anna Żakiewicz (ed.), Słupsk 1999.

Rawicz Jerzy, Do pierwszej krwi, Spółdzielnia Wydawnicza „Czytelnik”, Warsaw 1974.

Richter Hans, Dadaizm. Sztuka i antysztuka, trans. Jacek Stanisław Buras, afterword Werner Haftman, Wydawnictwa Artystyczne i Filmowe, Warsaw 1983.

Rimbaud Arthur, Korespondencja Artura Rimbaud, trans. and editing Julia Hartwig, Artur Międzyrzecki, Spółdzielnia Wydawnicza „Czytelnik”, Warsaw 1970.

Rorty Richard, Przygodność, ironia i solidarność, trans. Wacław Jan Popowski, Wydawnictwo Spacja, Warsaw 1996.

Savatier Thierry, Początek świata. Historia obrazu Gustave'a Courbeta, trans. Krystyna Belaid, Wydawnictwo słowo/obraz terytoria, Gdansk 2015.

Stanisław Ignacy Witkiewicz: człowiek i twórca. Księga pamiątkowa, Kotarbiński Tadeusz, Jerzy Eugeniusz Płomieński (ed.), Państwowy Instytut Wydawniczy, Warsaw 1957.

Surrealizm. Teoria i praktyka literacka. Antologia, selection and trans. Adam Ważyk, Spółdzielnia Wydawnicza „Czytelnik”, Warsaw 1976.

Tomkins Calvin, Duchamp. Biografia, trans. Iwona Chlewińska, Zysk i S-ka Wydawnictwo, Poznan 1996.

Vila-Matas Enrique, Krótka historia literatury przenośnej, trans. Joanna Karasek, Wydawnictwo Literackie MUZA SA, Warsaw 2007.

Witkiewiczowa Jadwiga, Wspomnienia o Stanisławie Ignacym Witkiewiczu, in: S.I. Witkiewicz, Listy do żony (1936-1939), prepared by A. Micińska, J. Degler (ed.), Państwowy Instytut Wydawniczy, Warsaw 2012.

Sara Kurowska

\section{Freedom of self-discreditation. On Witkacy's letters to his wife}

\section{(Summary)}

„If these letters are to be found by someone after my death, I will be brought into disrepute (...)" - wrote Witkacy to Jadwiga and he reminded his wife of destroying all the letters she receives from him. The question what and why could put the artist in disgrace seems fundamental and not so simple as one could assume. In order to find answer to this question I analyze letters in reference to Witkacy's theory of Pure Form. According to Marshall Berman, the elements of antimodernity in modernism, i.e. an art which strived for originality and innovation, were of utmost importance because due to them the artist keeps his identity. Witkacy, an artist from the provinces, who wished to become an artist fitting modern West European art, and who tailored his theory of Pure Form to that, did not express his anti-modernist resistance directly. His resistance is visible in creating low, carnal, trivial and autobiographic forms - brought into disrepute from 
the point of view of modernist art and Witkacy's own theory. Thus in his letters to his wife, Witkacy found a peculiar area of freedom - freedom of self-discreditation. Although he constantly blamed Jadwiga for lack of interest in philosophy, he was glad to communicate with her via the low art and low carnality.

Keywords: Witkacy's letters to his wife, Pure Form, carnality, innards, low art, self-discreditation, correspondence, autobiographic, novel pact 